\title{
GROWTH RESPONSE OF NORTH AFRICAN CATFISH FRY TO ORGANIC AND INORGANIC FERTILIZERS
}

\author{
Martins A. ANETEKHAI ${ }^{1}$, Fatai G. OWODEINDE ${ }^{1}$, Abiodun A. DENLOYE ${ }^{2 *}$, \\ Shehu L. AKINTOLA ${ }^{1}$, Oluwatoyin J. ADERINOLA ${ }^{2}$, Julius I. AGBOOLA ${ }^{1}$ \\ ${ }^{1}$ Department of Fisheries, ${ }^{2}$ Department of Zoology, Lagos State University, \\ Ojo, P.M.B. 1087, Apapa, Lagos, Nigeria
}

Anetekhai M.A., Owodeinde F.G, Denloye A.A., Akintola S.L., Aderinola O.J., Agboola J.I., 2005. Growth response of north African catfish fry to organic and inorganic fertilizers. Acta Ichthyol. Piscat. 35 (1): 39-44.

Background. Fertilizer application is considered a viable low-cost method of sustainable aquaculture production. This study was carried out to investigate the growth response of north African catfish, Clarias gariepinus (Burchell, 1822), fry to inorganic- (NPK) and organic (cow dung and poultry dropping) fertilizers.

Materials and methods. Catfish fry $(0.05-0.06 \mathrm{~g})$ were transferred for six weeks into a $0.13-\mathrm{m}$ deep, culture units of the surface area of $0.135 \mathrm{~m}^{2}$. Each culture unit was treated with either cow dung $+\mathrm{NPK}\left(\mathrm{T}_{1}\right)$, poultry dropping $\left(\mathrm{T}_{2}\right)$, cow dung + poultry dropping $\left(\mathrm{T}_{3}\right)$, control with no fertilizer $\left(\mathrm{T}_{4}\right), \mathrm{NPK}+$ poultry dropping $\left(\mathrm{T}_{5}\right)$, cow dung $\left(\mathrm{T}_{6}\right)$, NPK + cow dung + poultry dropping $\left(\mathrm{T}_{7}\right)$, and NPK $\left(\mathrm{T}_{8}\right)$.

Results. Fertilizer type was found to influence the quality and quantity of plankton, which in turn determined the growth and well-being of catfish fry. The best weight increase was recorded in $\mathrm{T}_{1}(1.37 \pm 1.01 \mathrm{~g})$ followed by $\mathrm{T}_{2}(0.49 \pm 0.31 \mathrm{~g})$, and then $\mathrm{T}_{7}(0.40 \pm 0.23 \mathrm{~g})$. The survival rate in $\mathrm{T}_{1}(100 \%)$ and $\mathrm{T}_{2}(60 \%)$ were the highest relative to the control $\left(\mathrm{T}_{4}\right)(87 \%)$. Dissolved oxygen, $\mathrm{pH}$, and temperature of culture water were variously affected by the treatments.

Conclusion. The results indicate that mixture of NPK and either cow dung or poultry droppings would adequately cater for the growth needs of $C$. gariepinus fry before feeding on compounded diet.

Key words: fish, growth, Clarias gariepinus, fry, fertilizers, poultry droppings, NPK, cow dung

\section{INTRODUCTION}

The genus Clarias is widespread in Africa and southeast Asia and its utilization for fish culture has significantly increased (Bard et al. 1976). The north African catfish, Clarias gariepinus (Burchell, 1822) has been considered a very important food fish in Nigeria (Ayinla 1988) and the most favoured pond-cultured fish species in Africa (Bard et al. 1976). Micha (1973) observed that C. gariepinus is ideal for culture because of its tolerance to low dissolved oxygen, rapid growth rate and acceptability of a variety of food items. Davy and Chouinard (1980) noted that the most critical area of fish fry production and the major critical period is immediately before and during the initiation of first feeding. If food is not immediately available to fish hatchlings the fry may become weak and become predisposed to predation in natural rearing systems (Rana 1990). If the initial feeding of C. gariepinus fry is delayed beyond 5.4 days, more than $50 \%$ of the fish may die (Owodeinde et al. 2004). Availability of food dur- ing initial feeding is thus very essential for the survival and growth of fish. Huisman et al. (1976) considered the lack of suitable food as the main cause of mortality in most fishes at this stage, emphasizing the importance of, not only, of the quantity and quality, but also the feed size.

Live food such as Artemia, Daphnia, rotifers, and copepods are the most satisfactory "first food" for fry (Bard et al. 1976). After this transition period of two weeks the fry can detect and eat artificial food (Madu et al. 1993). Consumption of live food during the first four days of feeding ensures adequate survival of $C$. gariepinus fry (cf. Adeyemo et al. 1992). Micha (1973) analysed the stomach contents of 15-day-old C. gariepinus fry and reported that the entire food contents was zooplankton, and that beyond that age the contents changed to larvae of aquatic insects and eventually artificial feed.

Most hatchery operations in Nigeria rely on brine shrimp, Artemia salina as the fry feed. Artemia is imported into the country and it is very expensive. This study 
therefore attempts to overcome this problem, particularly at the subsistence level; through application of the appropriate fertilizers to boost natural productivity that could sustain the fry to stage when they can readily accept compounded diet.

\section{MATERIALS AND METHOD}

Clarias gariepinus fry were produced in the fisheries laboratory of the Lagos State University using hormonal induced spawning, artificial fertilization, and incubation techniques. The hatchlings (average weight of $0.05-0.06 \mathrm{~g}$ ) after yolk absorption were transferred into culture unit of $0.135 \mathrm{~m}^{2}$ with water filled to a depth of $0.13 \mathrm{~m}$, and allowed to stay for six weeks. Fertilizers were earlier applied to the seven culture units as shown in Table 1 while the remaining tank had no fertilizer and served as the control. Each treatment was replicated three times and allowed to stand for five days, before transferring 15 fry into them. The quantity of fertilizer used is as recommended by FAO (Andren 1975).

The water quality parameters in the tank were monitored three times daily. The temperature was recorded using mercury-in-glass thermometer; $\mathrm{pH}$ was determined using Griffin pH meter model 40, and the dissolved oxygen measured using Winkler's method.

Qualitative and quantitative plankton analyses were carried out by filtering one litter of water sample taken from each of the tanks using plankton net. The concentrate was then fixed in a reagent bottle using formalin solution.

A light microscope was used to identify the plankton, according to a taxonomic key (Prescott 1984). The estimated count of different plankton items present was obtained by using Sedgewick rafter (approximately $500 \times$ $20 \times 1 \mathrm{~mm})$. The bottom area was divided into 1000 squares. The fish were sampled weekly using a scoop net and then weights and lengths measured. The same procedure was adopted for every tank.
Length and weight of the fry were used to determine the growth condition (condition factor, K) (Le Cren 1951). of fish using the relationship:

$$
K=\frac{100 \times W}{L^{3}}
$$

where:

$W$, fresh weight $[\mathrm{g}]$;

$L$, standard length $[\mathrm{cm}]$

Analysis of variance was performed to establish significant differences arising from treatment effects. Least significant difference (LSD) was used to identify differences in means of temperature, dissolved oxygen, $\mathrm{pH}$, plankton abundance, increase in fish length, and increase in fresh weight respectively following Sokal and Rohlf (1995).

\section{RESULTS}

Mean increase in length and weight, temperature, dissolved oxygen, $\mathrm{pH}$ and plankton abundance are shown in Table 2. The mean temperature in all the tanks ranged from $24.9 \pm 1.3^{\circ} \mathrm{C}$ to $25.6 \pm 1.1^{\circ} \mathrm{C}$. The mean $\mathrm{pH}$ showed minimal variation (from $7.2 \pm 0.81$ to $7.8 \pm 0.89$ ). Dissolved oxygen content showed significant variation in all the treatments $\left(3.7 \pm 0.6 \mathrm{mg} \cdot 1^{-1}\right.$ to $\left.9.1 \pm 2.8 \mathrm{mg} \cdot \mathrm{l}^{-1}\right)$ while the values were low in $\mathrm{T}_{3}\left(3.7 \pm 0.6 \mathrm{mg} \cdot \mathrm{l}^{-1}\right)$ and $\mathrm{T}_{7}$ $\left(3.9 \pm 0.4 \mathrm{mg} \cdot \mathrm{1}^{-1}\right)$ while the highest value was recorded in $\mathrm{T}_{5}\left(9.1 \pm 2.8 \mathrm{mg} \cdot \mathrm{l}^{-1}\right) . \mathrm{T}_{4}\left(7.5 \pm 1.3 \mathrm{mg} \cdot \mathrm{l}^{-1}\right), \mathrm{T}_{1}(6.5 \pm$ $\left.0.8 \mathrm{mg} \cdot \mathrm{l}^{-1}\right), \mathrm{T}_{2}\left(6.5 \pm 0.8 \mathrm{mg} \cdot \mathrm{l}^{-1}\right)$, and $\mathrm{T}_{6}\left(4.8 \pm 0.7 \mathrm{mg} \cdot \mathrm{l}^{-1}\right)$ have values of the best range for fish culture.

Plankton abundance in all the treatments is presented in Table 3. $\mathrm{T}_{8}$ had highest plankton abundance $\left(12.38 \times 10^{3}\right)$ followed by $\mathrm{T}_{1}\left(10.55 \times 10^{3}\right), \mathrm{T}_{7}\left(9.86 \times 10^{3}\right)$ then $\mathrm{T}_{3}(9.76$ $\left.\times 10^{3}\right) . \mathrm{T}_{6}\left(7.14 \times 10^{3}\right)$, and $\mathrm{T}_{4}\left(5.96 \times 10^{3}\right)$ had the lowest plankton abundance.

The growth condition of $C$. gariepinus fry in different fertilizer treatments are summarized in Table 2. $\mathrm{T}_{1}$ gave

Fertilizer treatments in individual tanks

Table 1

\begin{tabular}{cccc}
\hline \multirow{2}{*}{ Treatment } & Fertilizer type & Quantity per $0.1353 \mathrm{~m}^{2}$ & Quantity per 1 ha \\
\hline $\mathrm{T}_{1}$ & cow dung + NPK & $225 \mathrm{~g}+0.34 \mathrm{~g}$ & $15000 \mathrm{~kg}+25 \mathrm{~kg}$ \\
$\mathrm{~T}_{2}$ & poultry dropping & $270 \mathrm{~g}$ & $20000 \mathrm{~kg}$ \\
$\mathrm{~T}_{3}$ & cow dung + poultry dropping & $225 \mathrm{~g}+135 \mathrm{~g}$ & $15000 \mathrm{~kg}+10000 \mathrm{~kg}$ \\
$\mathrm{~T}_{4}$ & control & - & - \\
$\mathrm{T}_{5}$ & $\mathrm{NPK}+$ poultry dropping & $0.34 \mathrm{~g}+135 \mathrm{~g}$ & $25 \mathrm{~kg}+10000 \mathrm{~kg}$ \\
$\mathrm{~T}_{6}$ & cow dung & $450 \mathrm{~g}$ & $30000 \mathrm{~kg}$ \\
$\mathrm{~T}_{7}$ & $\mathrm{NPK}+$ cow dung + poultry dropping & $0.225 \mathrm{~g}+150 \mathrm{~g}+90 \mathrm{~g}$ & $16.6 \mathrm{~kg}+10000 \mathrm{~kg}+6666 \mathrm{~kg}$ \\
$\mathrm{~T}_{8}$ & NPK & $0.675 \mathrm{~g}$ & $50 \mathrm{~kg}$ \\
\hline
\end{tabular}

NPK contains nitrogen, phosphate, and potassium in ratio $15: 15: 15$ 
$\frac{\sqrt{\frac{\pi}{0}}}{\frac{0}{n}}$

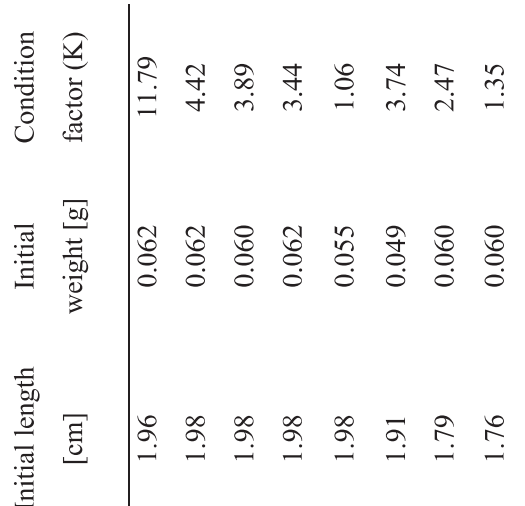

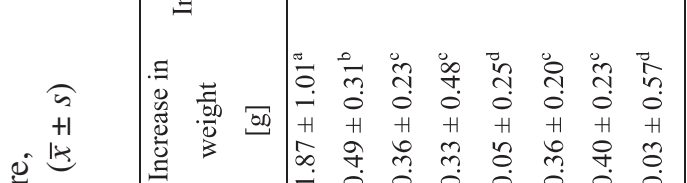


$\frac{m}{\frac{0}{\frac{0}{\sigma}}}$

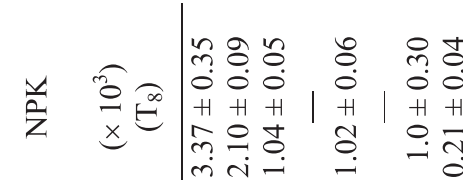

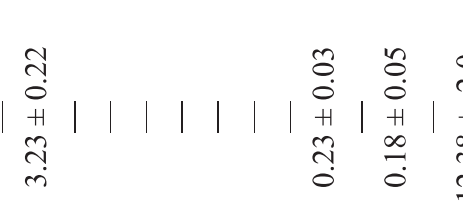

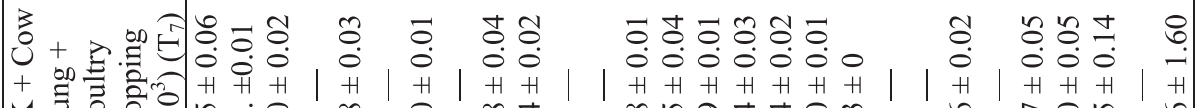

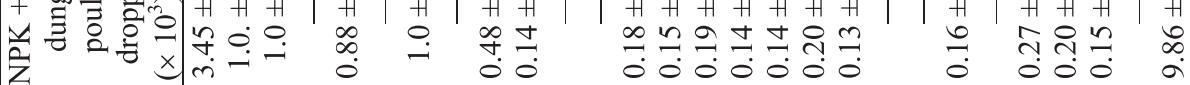

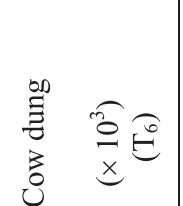

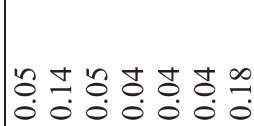

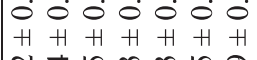
는

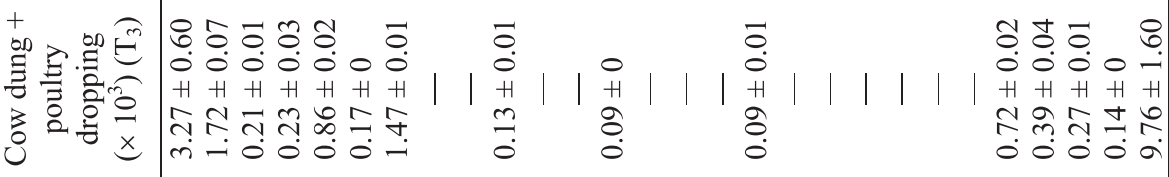

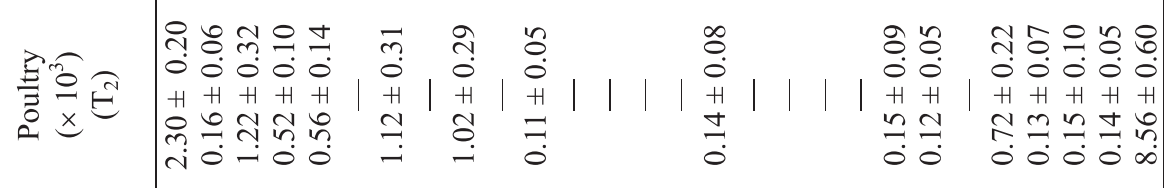

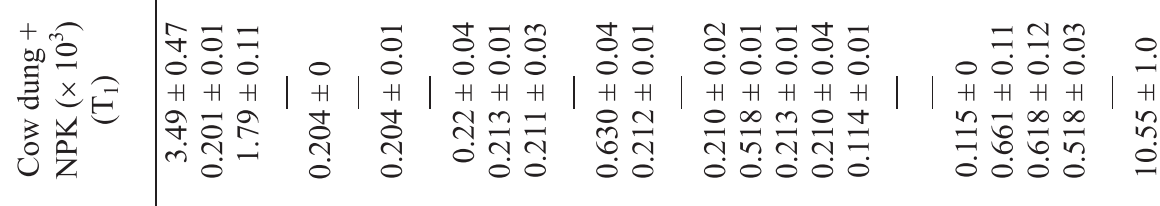
吉

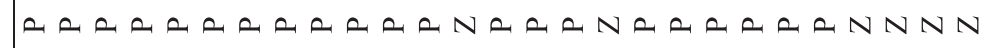

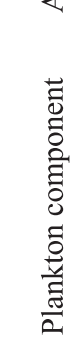

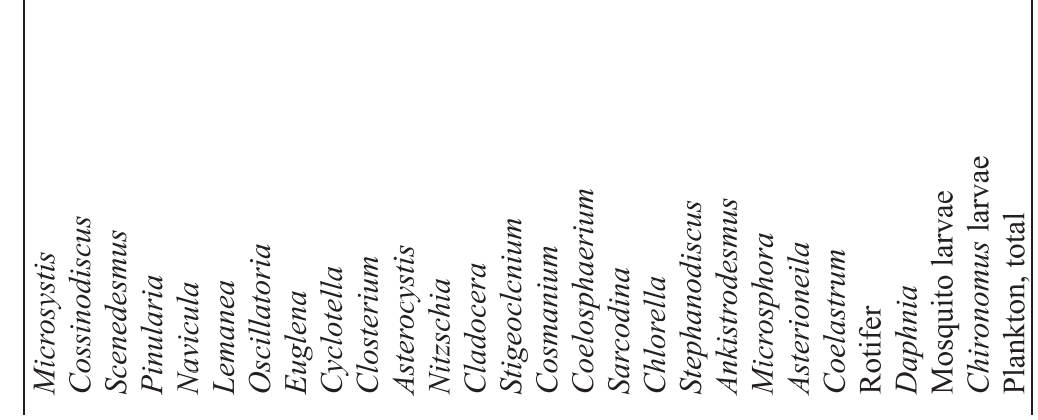




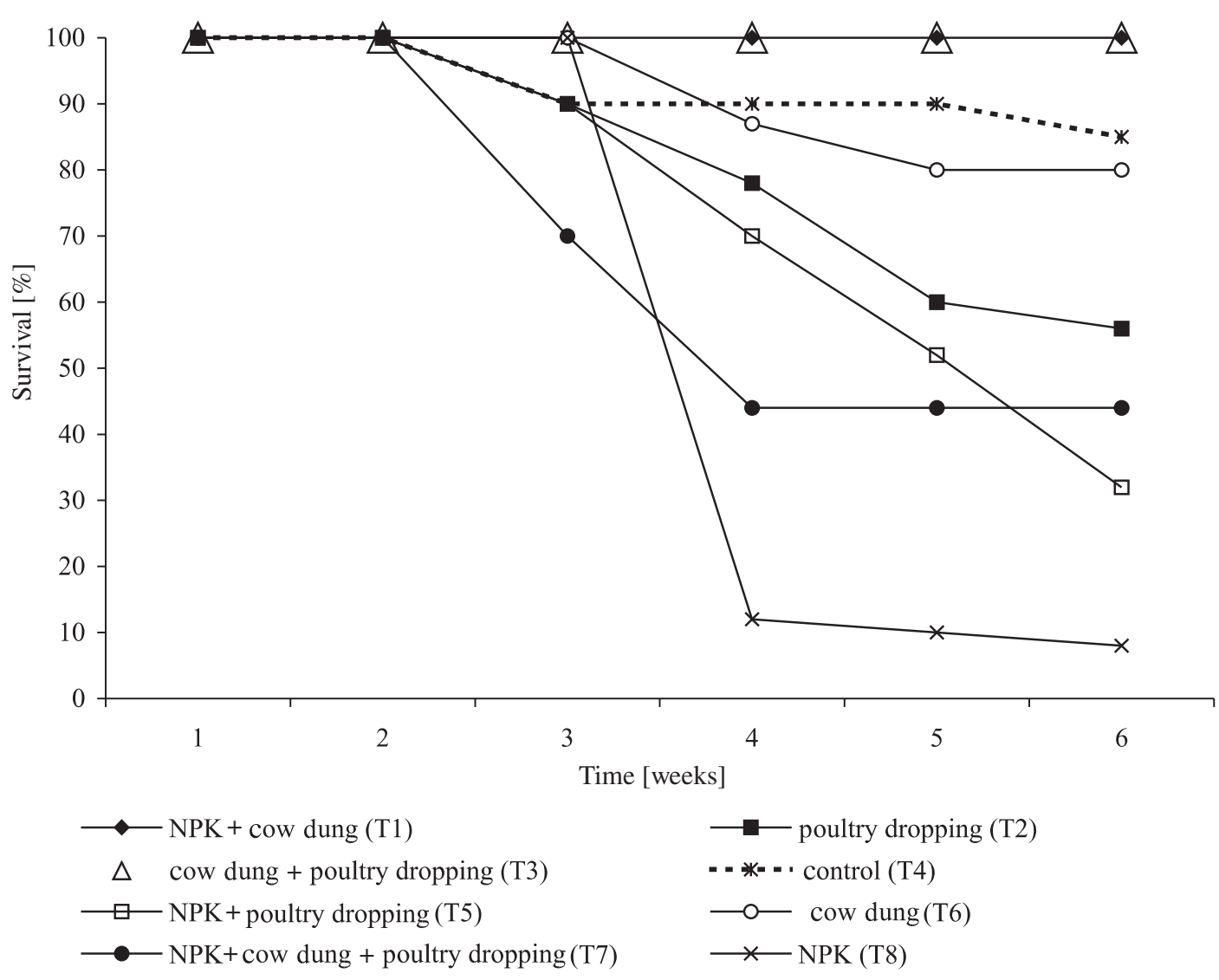

Fig. 1. Survival of Clarias gariepinus fry in various fertilizer treatments

the best weight increase of $1.87 \pm 1.01 \mathrm{~g}$ with condition factor $(\mathrm{K})$ of 11.79 and a corresponding $100 \%$ fish survival (Fig. 1). This was followed by $\mathrm{T}_{2}$ with weight increase of $0.49 \mathrm{~g}$ and $K$ of 4.42. Fry in $\mathrm{T}_{5}, \mathrm{~T}_{7}$, and $\mathrm{T}_{8}$ had $K$ values lesser than the control, $\mathrm{T}_{4}(3.44)$. $\mathrm{T}_{5}$ yielded the smallest $K$ value (1.06).

\section{DISCUSSION}

Fertilizer treatments used in the presently-reported study increased plankton abundance. This agrees with the findings of Tidwell et al. (2000), Azim et al. (2001), Keshavanath et al. (2001), and Dharmaraj et al. (2002). The best growth performance in terms of well-being, growth rate, and survival rate was recorded in treatment with $\mathrm{T}_{1}$. This may partly result from the superiority of plankton in terms of quantity and quality generated by the nutrients. It may also be due to high production of rotifers $\left(0.661 \times 10^{3}\right)$ and Daphnia spp. $(0.61$ $\left.\times 10^{3}\right)$ as shown in Table 3 . These zooplankters are among the most preferred food for fry (Micha 1973, Bard 1976).

The dissolved oxygen was most optimal on $\mathrm{T}_{1}$ for feeding and growth as reflected in highest condition factor (K) of 11.79 and $100 \%$ survival rate. Poultry dropping $\left(\mathrm{T}_{2}\right)$, which has the second best growth also showed a similar pattern of plankton composition with $\mathrm{T}_{1}$. The zooplankton abundance $\left(1.14 \times 10^{3}\right)$, in this treatment was however lower than the value obtained from $\mathrm{T}_{3}\left(1.70 \times 10^{3}\right)$ with fry weight increase of $0.36 \pm 0.23 \mathrm{~g}$.

The reason for the low growth value could be attributed to a low level of dissolved oxygen $\left(3.7 \mathrm{mg} \cdot \mathrm{1}^{-1}\right)$ in the
$\mathrm{T}_{3}$ treatment. The poor dissolved oxygen in this treatment could result from the phosphorus content of poultry dropping which in turn enhances eutrophication and consequently, depletes dissolved oxygen content (Blais et al. 2000). Also cow dung is a known source of nutrients and so is responsible for eutrophication in water bodies (Chale 2003). Both cow dung and poultry dropping may therefore have contributed, respectively, to oxygen depletion of the treated water due to plankton growth.

In $\mathrm{T}_{5}$ and $\mathrm{T}_{8}$ there was poor growth in of fish ( 0.05 and $0.03 \mathrm{~g}$, respectively). $\mathrm{T}_{8}$, though highest in plankton abundance $\left(1.24 \times 10^{4}\right)$ compared with all other treatments, had very low species diversity ( 2 zooplankters and 7 phytoplankters). The zooplankton count $\left(4.1 \times 10^{2}\right)$ was equally low. These two treatments $\mathrm{T}_{5}$ and $\mathrm{T}_{8}$ were the only treatments that produced Coelosphaerium $\left(3.72 \times 10^{3}\right.$ and $3.23 \times 10^{3}$ respectively). These blue-green algae could inhibit growth. Total lack of Scenedesmus in these two treatments could also create a vacuum in the food chain of C. gariepinus. The survival of fry in the two tanks was very low, 33 and $8 \%$, respectively.

The mean temperature range of $24.9 \pm 1.3^{\circ} \mathrm{C}$ to $25.6 \pm$ $1.1^{\circ} \mathrm{C}$ falls within the range $\left(24\right.$ to $\left.32^{\circ} \mathrm{C}\right)$ reported by Boyd (1979) as the best temperature tropical fishes eat and grow fastest and so could not have directly influenced the growth disparity in the experiment. This is also true for $\mathrm{pH}$, which was within the range of 6.5-9 recorded by Boyd (1979). 


\section{REFERENCES}

Adeyemo A.A., Ayinla O.A., Oladosu E.A., 1992. Growth and survival of the fry of selected culturable catfish species nursed on the cultured Monia dubia in comparison with other sources. Nigerian Institute of Oceanography and Marine Research (NIOMR), Technical Paper 78.

Andern L.E., 1975. Pollution and degradation of the environment affecting aquaculture in Africa. FAO/CIFA Symposium on Aquaculture in Africa, Accra, Ghana, 30 Sept.-5 Oct. 1975. CIFA/75/SR 12.

Ayinla O.A., 1988. Nutrition and reproduction performance of Clarias gariepinus. Nigerian Institute of Oceanography and Marine Research (NIOMR), Weekly Seminars.

Azim M.E., Wahab M.A., van Dam A.A., Beveridge M.C.M., Verdegem M.C.J., 2001. The potential of periphyton-based culture of two Indian major carps rohu Labeo rohita (Hamilton) and gonia Labeo gonius (Linnaeus). Aquaculture Research 32: 209-216.

Bard J.D.E., Kimpe P., Lizard S., Lemansson N.J., Lentessent T.P., 1976. Handbook of Tropical Culture Center Tech. Paper. Forestlier Trop. France.

Blais J.M., Duff K.E., Schindler D.W., Smol J.P., Leavitt P.R., Agbeti M., 2000. Recent eutrophication histories in Lac Ste. Anne and Lake Isle, Alberta, Canada inferred using paleolimonological methods. Lake and Reservoir Management 16: 292-304.

Boyd C.E., 1979. Water quality in warm water fish ponds. Auburn University Agricultural Experimental Station, Auburn, Alabama.

Chale F.M.M., 2003. Eutrophication of Kigoma Bay Lake Tanganyika, Tanzania. Tanzania Journal of Science 29 (1): 17-24.

Le Cren E.D., 1951. The length-weight relationship and seasonal cycle gonad weight and condition in perch (Perca fluviatilis). Journal of Animal Ecology 20 (2): 201-219.

Davy F.B., Chouinard A., 1980. Induced breeding in South East Asia. The International Development Research Centre, Ottawa, Canada.

Dharmaraj M., Manissery J.K., Keshavanath P., 2002. Effect of a biodegradable substrate, sugarcane bagasse and supplemental feed on growth and production of fringe-lipped peninsula carp, Labeo fimbriatus (Bloch). Acta Ichtyologica et Piscatoria 32 (2): 137-144.
Huisman E.A., Skjervold H., Richeter C.J., 1976. Aspect of fish culture and fish breeding. Miscellaneous paper 13 (1976) Loudo Whoge School-Wageningen, The Netherlands.

Keshavanath P., Gangadhar B., Ramesh T.J., van Rooij J.M., Beveridge M.C.M., Baird D.J., Verdegem M.C.J., van Dam A.A., 2001. Use of artificial substrates to enhance production of freshwater herbivorous fish in pond culture. Aquaculture Research 32: 189-197.

Madu C.T., Mohammed S., Mezie A., Issa J., Ita E.O., 1993. Comparative growth, survival and morphometrics of Clarias gariepinus, Heterobranchus bidorsalis and their hybrid fingerlings. pp. 56-61. In: Annual Report, new Bussa, Niger State (Nigeria): National Institute for Freshwater Fisheries Research.

Micha J.C., 1973. Étude des populations piscicoles de l'Ubangui et tentatives de sélection et d'adaptation de quelques espèces à l'étang de piciculture. Centre Technique Forstier Tropical, Nogent-sur-Marne, France.

Owodeinde F.G., Ogunlaru K.A., Denloye A.A.B., Irunokhai F.O., Hammed A.M., 2004. The effects of delayed initial feeding on the survival of artificially-reared Clarias gariepinus fry. Journal of Tropical Biosciences 4: 19-22.

Prescott G.W., 1984. The algae: a review. Otto Koeltz Science Publishers, Koenigstein, Germany.

Rana K.J., 1990. The influence of maternal age and delayed initial feeding on the survival and growth of previously unfed Oreochromis niloticus (L) and O. mossambicus fry. Aquaculture 91: 295-300.

Sokal R.R, Rohlf F.J., 1995. Biometry: The principles and practice of statistics in biological research. Third edition. W.H. Freeman and Company, New York.

Tidwell J.H., Coyle S.D., van Arnum A., Weibel C., 2000. Production response of freshwater prawn, Macrobrachium rosenbergii to increasing amounts of artificial substrate in ponds. Journal of the World Aquaculture Society 31: 452-458.

Received: 2 December 2004 Accepted: 15 June 2005 